\title{
Decadal Variation in Microflora and Fauna in 10 Water Bodies of Bhopal, Madhya Pradesh
}

\author{
SUBRATA PANI, AMIT DUBEY and M.R. KHAN \\ Environmental Planning and Coordination Organization, Paryavaran Parisar, \\ Kachnar, E-5 Arera Colony, Bhopal - 462016., India. \\ http://dx.doi.org/10.12944/CWE.9.1.20
}

(Received: January 07, 2014; Accepted: February 05, 2014)

\begin{abstract}
Bhopal, the capital of Madhya Pradesh is gifted with number of water resources of multiple uses. However most of the water bodies have shrunken because of siltation, illegal land filling, conversion, and encroachment. The combination of all these factors ultimately resulted in deterioration of water quality and loss of species. The present study therefore was undertaken to evaluate the impact of urbanization on water quality and bio-diversity of the 10 lakes and wetlands situated within the municipal area of the city. A comparison of data generated over the years depicts considerable reduction in total number of species in the water bodies like Upper Lake, Hathaikheda and Sarangpani Lake.
\end{abstract}

Key words: Urbanization, Impact, Variation ,Micro flora, Microfauna, Conservation and Management.

\section{INTRODUCTION}

Water is the basic and primary need of all vital life processes. Ever since the pre-historic times, man has been intimately associated with water and the evidences of past civilization that all historic human settlements were developed around inland freshwater resources have conclusively proved it. Even today, it is the major consideration for all socioeconomic cultural, industrial and technological developments. Besides drinking, water is also used for fish and aquaculture, irrigation hydropower generation etc. But these days, water the elixir of life, is becoming more and more unfit and dearer to mankind due to unwise use, neglect and mismanagement. Today water resources are the most exploited natural systems. The rapid urbanization and industrialization have caused population explosion in many urban centers and the generation of wastes both liquid and solid has grown to commendable proportions. The pace of development of waste disposal schemes could not match the rapid rate of urbanization in the urban centers during the last few decades. As a result the waste not properly disposed reaches the water sources and therefore our water sources like river, lakes and reservoirs that are in close proximity of these urban centers are highly polluted.

Bhopal the capital city of Central Indian State Madhya Pradesh has been blessed with number of water bodies of multipurpose uses. However with rapid urbanization and consequent changes in the demographic nature especially during second half of the last century all these water bodies have undergone severe degradation in their water quality due of inflow of sewage, dumping of solid wastes, inflow of silt, nutrient accumulation, flourishing growth of invasive aquatic plants and, depletion of bio-diversity and other anthropogenic activities.

Most of the water bodies in and around Bhopal are presently under great environmental 
stress due to pollution from point and non-point sources, flourishing aquatic vegetation, enrichment of nutrients and human encroachments. As a result, all the water bodies are gradually approaching towards eutrophication. Due to joining of untreated domestic sewage, washing activities etc., the water quality of these water bodies has deteriorated to a great extent thereby affecting the bio-diversity of the system.

\section{MATERIAL AND METHODS}

Water samples were collected from 10 water bodies situated in various parts of the city. During sampling 1 liter of water samples was collected by Ruttner Water Sampler and was filtered through the Nylobolt Plankton Net of mesh size 25 $\mu \mathrm{m}$ and concentrated to $50 \mathrm{ml}$ sub- sample. The collected sample was then preserved with $5 \%$ formaldehyde solution and iodine solution for analysis of zooplankton and phytoplankton sample respectively.

Analysis of the plankton samples were carried out using drop count methods under Trinocular microscope (Leica Image Analysis System). The results are expressed in organism / liter.

Table 1: Changes in Phytoplankton and Zooplankton community in Upper Lake during $2000-2010$

\begin{tabular}{lcc}
\hline Year & Phytoplankton & Zooplankton \\
\hline 2000 & 77 & 31 \\
2010 & 81 & 25 \\
$\%$ Changes & +5.19 & -19.35 \\
\hline
\end{tabular}

\section{RESULTS}

\section{Phytoplankton}

Upper Lake

Variation in total number of species in Upper Lake during the year during 2000-2010 is depicted below. The lake is an important Ramsar Site due its rich flora and fauna. In past more than 700 species of various categories of flora and fauna has been reported from this lake (Bajpai et al, 1997). In course of time although the number of phytoplankton species has reduced compared to the study reported by Bajpai et al, , however there has been insignificant changes in number of phytoplankton species when compared with data of 2010 with that of 2000 (Table-1). Although in during the intermittent years there has been significant fluctuation in total number of phytoplankton species due to climatic variability and anthropogenic pressures (S. Pani and S. M. Misra, 2000). Recurrence of the species (Figure-1) however depicts rejuvenation of the ecosystem which was damaged due to urban pressures. However a reduction in total number of zooplankton species has been observed when compared with the past (Table-1).

\section{Lower Lake}

The Lower Lake is a traditionally polluted water body due to influx of domestic sewage from its highly urbanized catchment. Impact of nutrient accumulation on biodiversity of this water body has been reported in many occasions (Misra et al 2001, Pani \& Sachdev, 2007). The lake inhabited about $50 \mathrm{sp}$ during the year 2000, which has drastically reduced to 31 species in 2011(Table -2). The lake continued to be enriched with high influx of sewage and autochthonous generation of organic matters which resulted in formation of algal blooms and a shift in dominance of species from

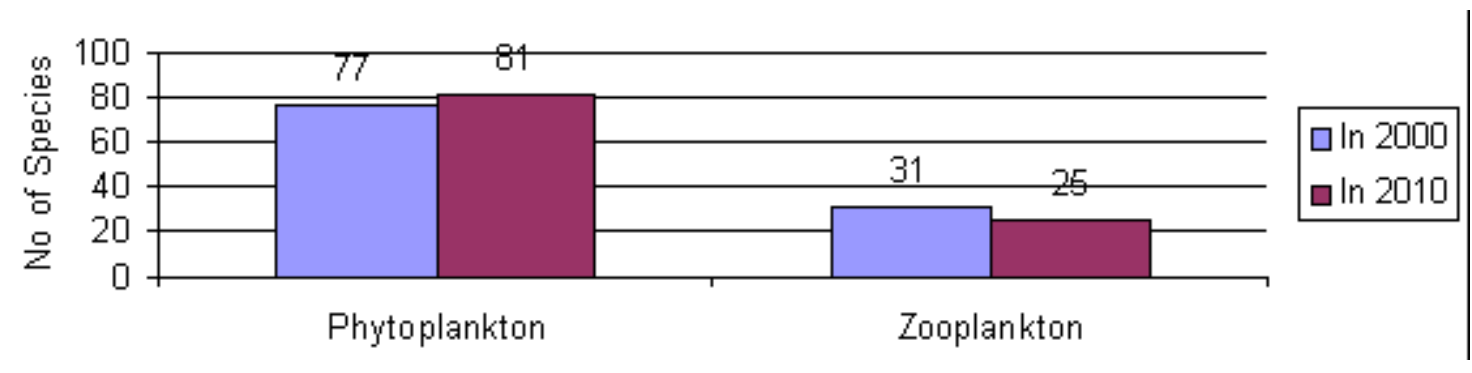

Fig. 1: Variation in Phyto and Zooplanktin In Upper Lake during the year 2000 \& 2010 
Table 2: Changes in Phytoplankton community in Lower Lake during 2000 - 2010

\begin{tabular}{lcc}
\hline Year & Phytoplankton & Zooplankton \\
\hline 2000 & 50 & 12 \\
2010 & 31 & 25 \\
$\%$ Changes & -38 & +108.33 \\
\hline
\end{tabular}

Bacillariophyceae and Oligophyceae to Cyanophyceae. Development of excessive quantity of Microcystis aeruginosa can be witnessed in this lake. The number of zooplankton species has increased due to dominance of class Rotifera which has resulted in succession of Cladocera and Copepoda groups.

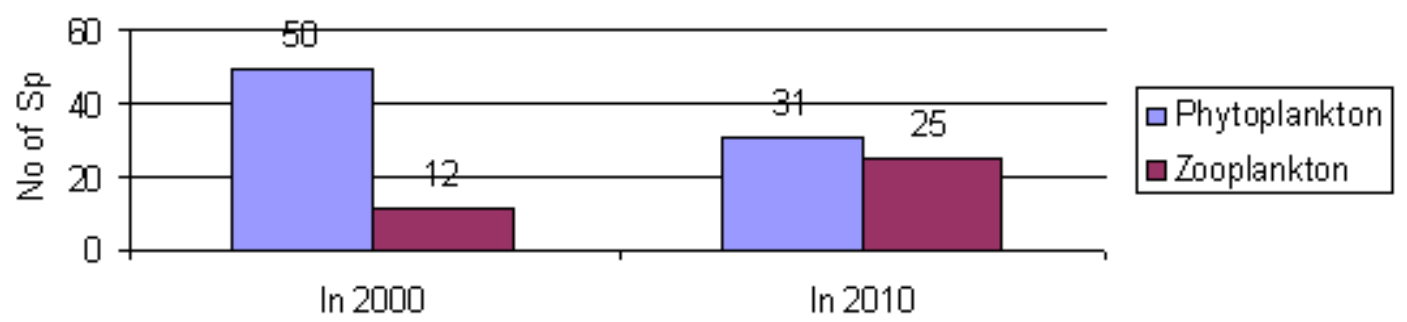

Fig. 2: Variation in Phyto and Zooplanktin In Lower Lake during the year 2000 \& 2010

\section{Sarangpani}

Sarangpani Lake is situated in BHEL area of Bhopal. The Lake after establishment of the BHEL, and subsequent development of the colonies in the adjoining areas, is being used as a settling tank of the sewage discharged from the adjoining settlements in absence of proper sewage networks. The inflow of sewage water over the years has resulted in deterioration of the water quality of the

\section{Table 3: Changes in Phytoplankton community in Sarangpani Lake during 2000 - 2010}

\begin{tabular}{lcc}
\hline Year & Phytoplankton & Zooplankton \\
\hline 2000 & 38 & 15 \\
2010 & 31 & 25 \\
$\%$ Changes & -18.42 & +66.66 \\
\hline
\end{tabular}

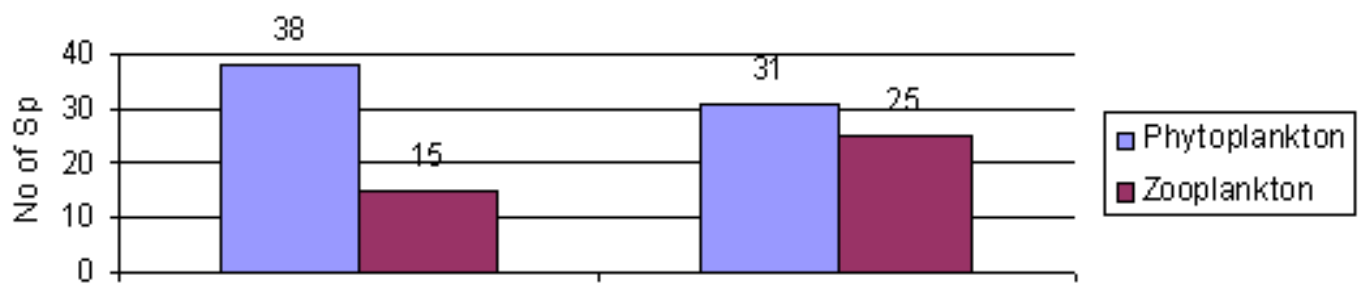

In 2000 lake. This has been manifested in the availability of plankton species in the lake. A reduction in Phytoplankton species has been observed in course of time (Table-3, Figure-3). However an increase in zooplankton species has been observed in due course of time which may be due to increase in number of Rotifer community.

\section{Laharpur}

Laharpur dam was constructed in the southwest corner of Bhopal city with an objective to store water for irrigational use. At the time of planning and construction of the reservoir, it was in the outskirts of the township but with the expansion of the city, the developmental activities and occupancy in the area (Pandey et al 2008) has exerted pressure on the water body resulting in reduction in number of both phytoplankton and zooplankton species (Table-4, Figure-4).

Fig. 3: Variation in Phyto and Zooplanktin In Sarangpani during the year 2000 \& 2010 
Table 4: Changes in Phytoplankton community in Laharpur Reservoir during $2000-2010$

\begin{tabular}{lcc}
\hline Year & Phytoplankton & Zooplankton \\
\hline 2000 & 12 & 9 \\
2010 & 11 & 4 \\
$\%$ Changes & -8.33 & -11.11 \\
\hline
\end{tabular}

Char Imli

Char Imli pond is a perennial water body situated in the heart of the city. Although it is a small water body but attracts large number of people. The topography of the pond provides under ground springs to make up the water level of the pond. This water body also receives huge quantity of raw sewage from the adjoining slum areas in absence of proper sewage net works. A reduction in both

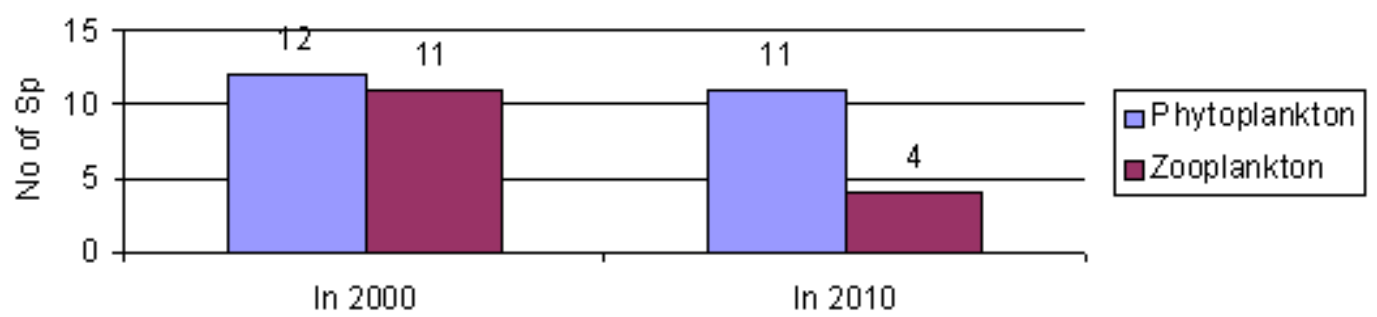

Fig. 4: Variation in Phyto and Zooplanktin In Laharpur Reservoir during the year 2000 \& 2010

Table 5: Changes in Phytoplankton community in Char Imli Pond during 2000 - 2010

\begin{tabular}{lcc}
\hline Year & Phytoplankton & Zooplankton \\
\hline 2000 & 12 & 22 \\
2010 & 7 & 17 \\
$\%$ Changes & -41.66 & -22.72 \\
\hline
\end{tabular}

Table 6: Changes in Phytoplankton community in Shahpura Lake during 2000 - 2010

\begin{tabular}{lcc}
\hline Year & Phytoplankton & Zooplankton \\
\hline 2000 & 12 & 22 \\
2010 & 9 & 14 \\
$\%$ Changes & -25 & -36.36 \\
\hline
\end{tabular}

the categories of phytoplankton and zooplankton species has been observed in course of time (Table-5, Figure-5).

\section{Shahpura}

Shahpura Lake is a manmade water impoundment, which was formed in 1974-1975 under the Betwa irrigation scheme, after constructing an earthen dam near Chunabhatti village in the south part of the Bhopal City. However the lake water is not being used for irrigation but it serves secondary purpose of recreation and as waterfront to the residents.

The main source of water to the lake is the storm water but during dry weather condition the sewage fed drains regularly drain water in the lake. The other part of the lake also receives untreated sewage and wastewater from the eastern, northern and southeastern part of the lake. Thus the inflow of

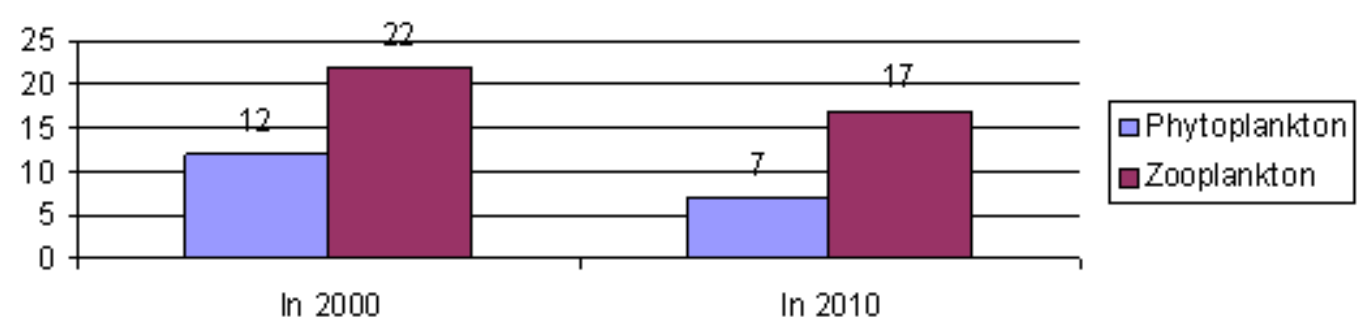

Fig. 5: Variation in Phyto and Zooplanktin In Char Imli during the year 2000 \& 2010 


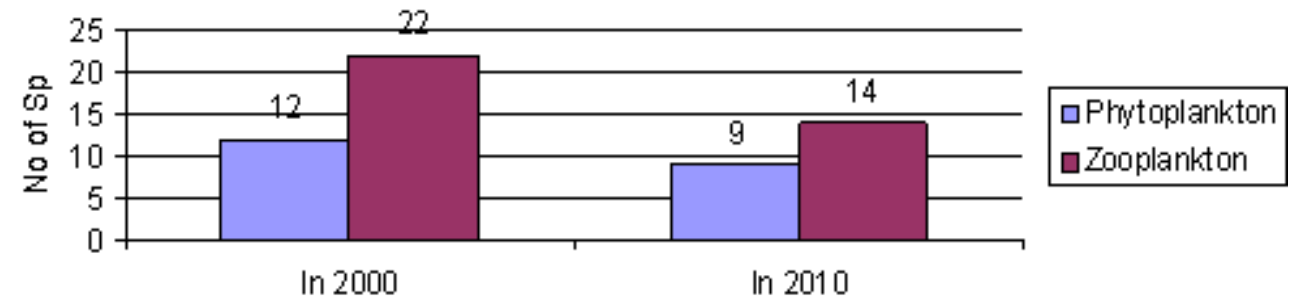

Fig. 6: Variation in Phyto and Zooplanktin In Shahpura during the year 2000 \& 2010

nutrient rich sewage and run off water especially in last decade has resulted in reducing the number of phytoplankton and zooplankton species in the lake (Table-6, Figure-6).

\section{Motia Talab}

Motia tank, a perennial water body is located adjacent to the Taj-ul-Masjid on the northwest of the Bhopal City. It is a man-made lake, constructed in the late $19^{\text {th }}$ Century A.D. It was initially meant to provide pre-prayer ablution facility to the Muslim devotees visiting the monumental Taj-ul-Masjid. The water body has important aesthetic value and is situated in the densely populated area of the old city of Bhopal. It is surrounded on its northern side by the historic Taj Mahal palace, on the southern side by Asia's biggest mosque Taj-ul-Masjid, on the western side by picturesque architecture of Benazeer Palace and on the east by Thelawala Sadak.

Table- 7: Changes in Phytoplankton community in Motia Talab during 2000 - 2010

\begin{tabular}{lcc}
\hline Year & Phytoplankton & Zooplankton \\
\hline 2000 & 12 & 22 \\
2010 & 8 & 13 \\
$\%$ Changes & -33.33 & -40.90 \\
\hline
\end{tabular}

This water body is presently under great environmental stress due to pollution from point and non-point sources resulting in eutrophication, fast growth of aquatic macrophytes, enrichment of nutrients and human encroachments. As a result of these, this water body is gradually getting filled up leading towards advance stages of eutrophication. Since this tank is facing serious problem of eutrophicatoin due to joining of untreated domestic sewage, Nistar and washing activities etc., which are mainly responsible for deterioration of water quality, and also reducing the carrying capacity of the system and the Phyto and Zooplankton species (Table-7, Figure-7).

\section{Munshi Hassan}

This lake is situated amidst the old city of Bhopal near Taj-ul-Masjid on the northwest of the Bhopal City. The out flow of Siddiqui Hussain tank is a major source of water for Munshi Hussain tank. This tank is one of the important aquatic reservoirs

Table 8: Changes in Phytoplankton community in Munshi Hassan during 2000 - 2010

\begin{tabular}{lcc}
\hline Year & Phytoplankton & Zooplankton \\
\hline 2000 & 13 & 7 \\
2010 & 9 & 4 \\
$\%$ Changes & -30.76 & -42.85 \\
\hline
\end{tabular}

22

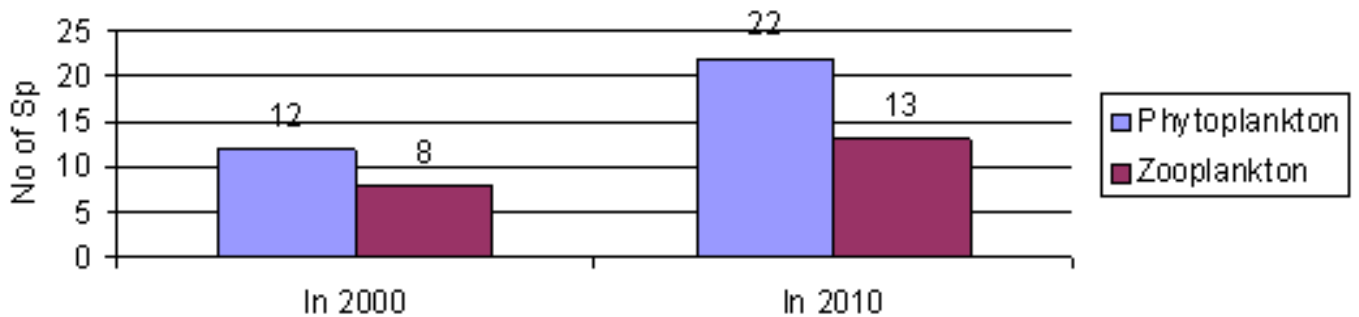

Fig. 7: Variation in Phyto and Zooplanktin In Motia Talab during the year 2000 \& 2010 


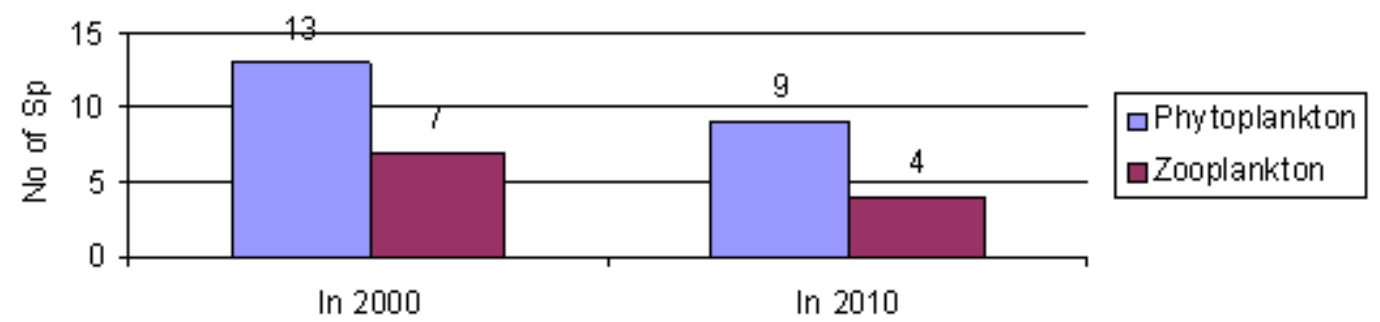

Fig. 8: Variation in Phyto and Zooplanktin In Mushi Hussain during the year 2000 \& 2010

because it is the only deep-water body situated in the densely populated area of the old city. It is also connected with the religious activities of the Muslim community. It is a part of the exemplary water management system constructed by Muslim rulers, which resembles the water management system of Islam Nagar Fort. On earlier days, the rainwater flowing down the Idgah Hills was collected at a point for supply to the Benazeer palace. The wastewater from the palace used to join the Motia tank, which subsequently trickled down to Munshi Hussain Khan Tank. Thus a level was maintained in the tank.

The lake is subjected to high degree of pollution due to nutrient inflow from the thickly populated area. These lake remains covered with free-floating macrophytes during major part of the year and therefore availability of both Phytoplankton and Zooplankton has significantly reduced (Table8 \& Figure-8).

Table 9: Changes in Phytoplankton community in Siddiqui Hussain during 2000 - 2010

\begin{tabular}{lcc}
\hline Year & Phytoplankton & Zooplankton \\
\hline 2000 & 7 & 12 \\
2010 & 6 & 8 \\
$\%$ Changes & -14.28 & -33.33 \\
\hline
\end{tabular}

\section{Siddiqui Hussain}

The Siddiqui Hussain tank constructed in the year 1886 is completely filled with silt and vegetation. Only wet/muddy soil could be visible at site. A major part of the tank is illegally encroached for construction purposes. The water body represents fewer numbers of Phyto and Zooplankton species (Table-9 \& Figure-9).

\section{Hataikheda}

Hataikheda reservoir like many others in the state was constructed for irrigation but now it is an important water resource to supply water to the Industrial area of Govindpura and also used for fish culture. This is a multipurpose reservoir of Bhopal, situated about $5 \mathrm{~km}$ from BHEL Township in the northeast direction.

This reservoir also started getting polluted due to various types of development in its catchment fringe area of the reservoir. The inflow of

Table 10: Changes in Phytoplankton community in Hataikheda during 2000 - 2010

\begin{tabular}{lcc}
\hline Year & Phytoplankton & Zooplankton \\
\hline 2000 & 7 & 12 \\
2010 & 9 & 11 \\
$\%$ Changes & +28.57 & -8.33 \\
\hline
\end{tabular}

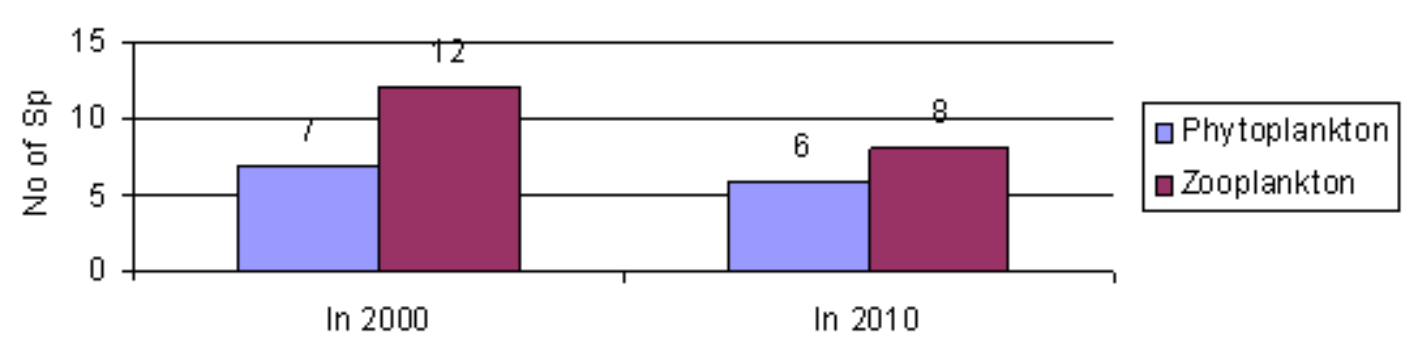

Fig. 9: Variation in Phyto and Zooplanktin In Siddiqui Hussain during the year 2000 \& 2010 


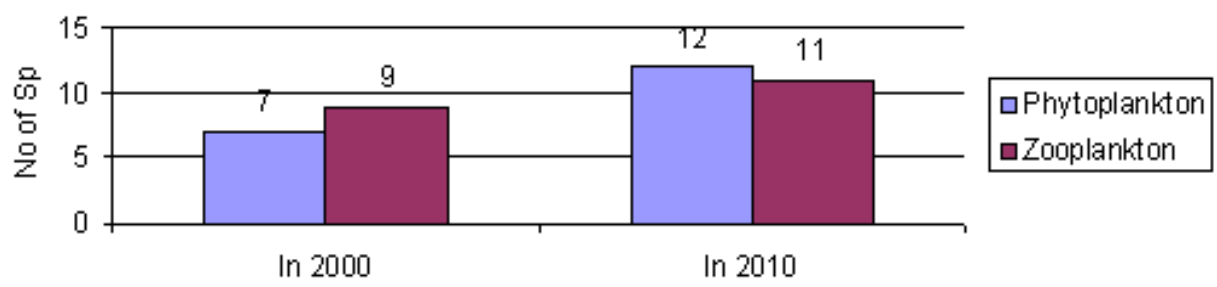

Fig. 10: Variation in Phyto and Zooplanktin In Hataikheda during the year 2000 \& 2010

Table 11: Changes in Phytoplankton community in Kaliasote Reservoir during $2000 \& 2010$

\begin{tabular}{lcc}
\hline Year & Phytoplankton & Zooplankton \\
\hline 2000 & 7 & 12 \\
2010 & 4 & 9 \\
$\%$ Changes & -42.85 & -25 \\
\hline
\end{tabular}

sewage from the newly developed satellite township of BHEL is the main cause for deterioration of the water quality. This reservoir though has a great potential of varied species of flora and fauna but the impact of urbanization again affected the availability of both Phyto and Zooplankton in the reservoir (Table-10 \& Figure$10)$.

\section{Kaliasote Reservoir}

In the down stream of Upper Lake, the Kaliasote reservoir was constructed to store out going water through Bhadbhada gates for the purpose of irrigation water supply.

This reservoir at present is suffering from siltation due to rapid change in land use pattern from agriculture to housing. The construction and development activities not only accelerated soil erosion rate in the catchment but also discharging untreated sewage in the reservoir. However the water body represents poor development of biotic community in absence of sufficient water (Table-11 \& Figure-11.

\section{DISCUSSION}

Aquatic biodiversity has enormous economic and aesthetic value and is largely responsible for maintaining and supporting overall

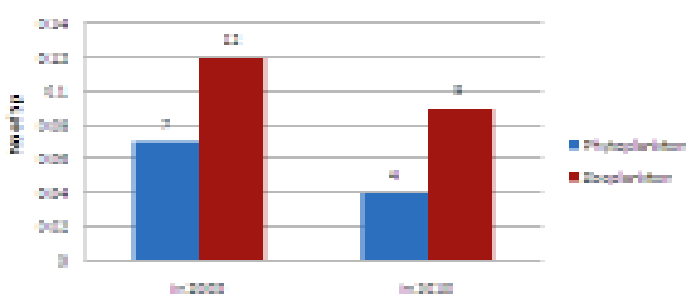

Fig.11: Variation in Phto and Zooplankton species in Kaliasote Reservoir during the year $2000 \& 2010$

environmental health. Humans have long depended on aquatic resources for food, medicines, and materials as well as for recreational and commercial purposes such as fishing and tourism (Bajpai et al 2000). Aquatic organisms also rely upon the great diversity of aquatic habitats and resources for food, materials, and breeding grounds.

However the bio-diversity in most of the urban areas is facing various problems, leading to extinction of large number of species (S. Pani and S.M.Misra, 2000). Factors including overexploitation of species, the introduction of exotic species, pollution from urban, industrial, and agricultural areas, as well as habitat loss and alteration through damming and water diversion are responsible for declining levels of biodiversity. As a result, valuable aquatic resources are becoming increasingly susceptible to both natural and artificial environmental changes (Bajpai et al 2001).

Thus, conservation strategies to protect and conserve aquatic life are necessary to maintain the balance of nature and support the availability of resources for future generations.

The major threats to freshwater biodiversity in the water bodies of Bhopal are runoff from agricultural and urban areas, inflow of sewage 
and the invasion of exotic species. Worldwide, most types of freshwater ecosystems generally are in grave condition and are declining at a much faster rate than terrestrial systems (Misra \& Pani, 2007).

The Upper lake Bhopal is traditionally an important wetland inhabiting more than 700 species of diverse groups. The wetland is also an important site of avian fauna with more than 150 species of both migratory and resident birds. However the rich biodiversity of the wetland in past few years has been subjected to various anthropogenic pressure and natural calamities, irregular rainfall during last decade being one of them. After 2007 a major part of the wetland becomes dried due to insufficient rain fall. The impact of dryness was observed to have major affect on species composition and availability. Because of dryness, a reduction in almost all groups of species viz. Phytoplankton, Zooplankton has been observed. The disturbances in the ecological niche have also affected the arrival of migratory birds in consequent years as less number of migratory birds have been reported (report published by Bhopal Birds) in the consecutive years. Recurrence of few species however recorded in the year 2010. The lower lake is still subjected to high degree of urban pressure. This resulted in reduction of number of species in due course of time. Almost similar situation have been experienced in other water bodies of the city. Thus the depletion in number of species in almost all the water bodies in the region necessitates the importance for their proper conservation through sustainable developments.

\section{ACKNOWLEDGEMENT}

The authors are very thankful to Chief Executive Officer of Lake Conservation Authority of MP Shri Manohar Dubey, Senior Indian Administrative Officer of Government of MP for his consistent help and encouragement in conducting this study.

\section{REFERENCE}

1. Bajpai A., Bajpai A.K., Pani. S. \& Borana. K. Biodiversity and strategies for Conservation, Proceedings of Biodiversity and conservation of aquatic resources $w / r$ to threatened fish Mahaseer, held at Bhopal on $26^{\text {th }} \& 27^{\text {th }}$ February 2000

2. Pani. S. and Misra. S.M. Biodiversity and trophic status of two tropical lakes of Bhopal, Proceedings of National Seminar on Biodiversity Conservation \& Management with Special Emphasis on Biosphere Reserve held at EPCO sponsored by MOEF Nov. 2000.

3. Bajpai. A., Bajpai. A.K., Pani. S. \& Misra. S.M. Pollution and Trophic Status indicator species of Bhoj Wetland Ecol. Env. \& Cons, 7(3): (245-249) (2001).

4. Misra. S.M., Pani. S., Bajpai. A. \& Bajpai. A.K. Assessment of trophic status by using Nygaard Index with special reference to Bhoj Wetland, Poll Res. 20(2): 1-7, (2001).
5. Misra. S.M. \& Pani Subrata. Conservation of aquatic ecosystems: Lessons learned from Bhoj Wetland, Technical Contributions, National seminar on Environment and Development, 16-17 Jan, 2006 Bhopal, organized by Environmental Planning \& Coordination Organization.

6. Pani Subrata \& Sachdev Sanjeev. Impact of remedial measures in conservation of aquatic resources: Lesson learned from Bhoj Wetland Project, , $12^{\text {th }}$ World lake Conference, Taal 2007, Jaipur 28october 2 November 2007, organized by Ministry of Environment \& Forests, Government of India under the auspices of International Lake Environment Committee Foundation (ILEC)

7. Pandey S.C., Pani S., and Malhosis Sadhna (2008) Studies on eco-toxicological status of Laharpur Reservoir, Bhopal (India) in relation to its conservation and management, Journal of Environmental Research and Development, 3(1), (2008). 